\title{
Primary School Teacher' Perceptions towards the Physical Education Component of Creative and Performing Arts Curriculum in Botswana 博茨瓦納小學教師對體育及創意藝術融合課程的認知
}

\author{
Lobone L. KASALE Martin M. MOKGWATHI \\ Department of Physical Education, Health and Recreation, \\ University of Botswana, Gaborone, BOTSWANA
}

盧邦・卡沙莉＼cjkstart馬田・蒙嘉華治

博茨瓦納大學體育、健康及康樂學系

\begin{abstract}
Creative and Performing Arts is a new subject that has been introduced at the primary school level in Botswana. The subject draws its contents from various disciplines such as Arts and Craft, Design and technology, Home Economics, Business Studies, Drama, Dance, Music and Physical Education. The aim of the study is to evaluate the perceptions of the primary school teachers with regards to teaching of the Physical Education component of Creative and Performing Arts curriculum. Nine primary schools in the greater Gaborone area were randomly selected for the purpose of this study. The data was collected by means of a questionnaire that was designed for the purpose of this study. The Cronbach Alpha was used to test the reliability of the instrument and a value of 0.73 was obtained in the test. The questionnaire was distributed among the primary school teachers who responded to it. Data analysis revealed that teachers were not adequately trained to demonstrate physical education skills and therefore had difficulties in teaching the subject. It is hence recommended that teachers who are required to teach the physical education component of Creative and Performing Arts must be qualified physical education professionals who will be able to correctly demonstrate physical education skills to the learners. In this way, students may be able to benefit from creative and performing arts as a curriculum subject.
\end{abstract}

Key words: Creative and Performing Arts; Beliefs; Perceptions

\section{摘 要}

本文旨在探討博茨瓦納小學的體育科與創意藝術科的融合，結果顯示需要培訓足夠的教師去教授這些融合的課程。

\section{Introduction}

In 1993 the government of Botswana launched a Commission on education. This commission prompted a revision of the National Policy on Education in 1994. The revised National Policy on Education advocated for the inclusion of physical education in the school system in the country. As a response to this recommendation, the Ministry of Education introduced the Physical Education subject to Junior Secondary School in 1994 and to Senior Secondary Schools in 2009. Creative and Performing Arts is a subject that was introduced to Primary Schools in Botswana in 2002.

The Government of Botswana's Ministry of Education introduced Creative and Performing Arts as a curriculum subject in Primary schools following a report to the Ministry of Education by Cream Wright in 1995. The 
report brought the idea that practical subjects namely Art, Music, Physical Education, Home Economics, Design and Technology which were taught as optional subjects at secondary school level could be grouped together to make one subject (Creative and Performing Arts Syllabus, 2002). The main objective of the subject is to help students to develop an understanding and appreciation of technology, manipulative skills and familiarity with tools, equipment and material. This objective is intended to help in meeting one of the goals of the Nation's Vision 2016, which states that the education system will be used to raise awareness on life skills such as self health care and to promote entrepreneurs who will create employment through the establishment of new enterprises. Table 1 shows the modules of Creative and Performing Arts for upper primary and lower primary.

Table 1. Creative and Performing Arts Modules of Primary Schools.

\begin{tabular}{|c|c|c|c|}
\hline Module & Subject & Lower Primary Topics & Upper Primary Topics \\
\hline Health and Safety & $\begin{array}{l}\text { Home Economics } \\
\text { Physical Education }\end{array}$ & $\begin{array}{l}\text { Safety precautions } \\
\text { Good Health Practices }\end{array}$ & $\begin{array}{l}\text { Hygiene } \\
\text { Safety and First Aid } \\
\text { Food } \\
\text { Exercise }\end{array}$ \\
\hline Communication & $\begin{array}{l}\text { Art } \\
\text { Music }\end{array}$ & $\begin{array}{l}\text { Drawing } \\
\text { Painting } \\
\text { Collage } \\
\text { Mosaic } \\
\text { Modeling } \\
\text { Illustration } \\
\text { Pattern making } \\
\text { Print making }\end{array}$ & $\begin{array}{l}\text { Drawing } \\
\text { Painting } \\
\text { Two dimensional crafts } \\
\text { Media }\end{array}$ \\
\hline $\begin{array}{l}\text { Listening, Composing and } \\
\text { Performing }\end{array}$ & $\begin{array}{l}\text { Music } \\
\text { Physical Education }\end{array}$ & $\begin{array}{l}\text { Sounds } \\
\text { Rhymes } \\
\text { Choreography } \\
\text { Body Percussions } \\
\text { Pitch } \\
\text { Dance } \\
\text { Games } \\
\text { Gymnastics }\end{array}$ & $\begin{array}{l}\text { Choreography } \\
\text { Body Percussions } \\
\text { Pitch and Durato } \\
\text { Dramatization } \\
\text { Dance } \\
\text { Games } \\
\text { Gymnastics }\end{array}$ \\
\hline Design and Making & Craft and Design & $\begin{array}{l}\text { Materials } \\
\text { Structures } \\
\text { Mechanisms } \\
\text { Design and making processes }\end{array}$ & $\begin{array}{l}\text { Materials } \\
\text { Structures } \\
\text { Mechanisms } \\
\text { Design and making processes }\end{array}$ \\
\hline
\end{tabular}


The table above shows the various subjects that make up the modules of Creative and Performing Arts. Module 1 on Health and safety comprises of both physical education and Home economics content. Module 2 on communication comprises of contents from Art and Music. Module 3 on listening composing and performing comprises of contents from Music and Physical Education. Module 4 on design and making comprises of content from design and craft.

According to Faulkner and Reeves (2000), Physical Education experiences at primary school level appear to have important implications for children's education, health, exercise adherence and general wellbeing. Physical education in schools therefore provides the means by which young people can learn how to participate and become involved in purposeful physical activities. They are hence able to make choices and select activities that can contribute to the enrichment of their lives and add immensely to the quality of living (Almond, 1997). Primary school children are at an optimal age for the development of motor skills and developing physical activity habits and for the formation of attitudes regarding physical activity and Physical Education.

The perceptions and attitudes of teachers towards teaching Physical Education therefore represents important factors affecting the quality of school Physical Education programs (Guan et al., 2002). Teachers who are effectively using a variety of pedagogical skills and strategies to ensure that their students are engaged in relevant activities most of the time hold positive expectations for their students, create and maintain classroom climate that is warm and nurturing (Wuest \& Bucher 1999). In Botswana, Primary school Physical Education is taught by teachers who have a minimum training in the subject matter (Mokgwathi, 1999). Teachers are currently trained in the Colleges of Education awarding Diploma in primary education. The colleges train both specialist and generalist teachers. College programmes do not allow adequate time for the study to physical education. A study Owolabi and Sewane (1996) conducted revealed that teachers who were expected to teach Physical Education reported that they had inadequate knowledge about the subject.
All teachers have beliefs about their work, their students, how learning occurs and the subject that they teach (Lefrancois, 2000). The personal beliefs and the limits of the national curriculum guide teacher's behaviors and decisions. The belief system reflects teacher's values and consequently influences the content of Physical Education lessons and how it will be taught (Behets, 2001). Research demonstrates the beliefs held by teachers' influence, their perceptions of education, instructional behaviors and student learning outcomes. Beliefs therefore play a pivotal role in how teachers interpret and act upon knowledge presented Matanin \& Collier, 2003).

Physical education has emerged from the initial period of supervised recess into a sophisticated subject that requires specialist teachers (Gabbard et al., 1994). The achievement of the goals and objectives of Physical Education needs qualified and interested teachers to teach the physical education curriculum (Owolabi, 1997). It is imperative that qualified and competent teachers should teach Physical Education (Morgan, et al., 2001). Competency in a variety of instructional skills is essential for effective teaching (Wuest \& Bucher 1999). While most research has indicated the importance of Physical Education to the development of the child, primary school physical education is inhibited by low status, reduced time in the school curriculum and poor quality programs (Morgan et al., 2002). Thus physical education is a subject that most teachers do not take seriously (Kim \& Taggard, 2004). The purpose of this study is therefore to find out the perceptions of primary school teachers with regards to teaching of the physical education component of Creative and Performing Arts in Botswana primary schools.

\section{Methodology}

The research is mainly explorative in nature and a survey was used for the purpose of data collection and analysis.

\section{Sample}

A total of seventy two (72) teachers from randomly selected primary schools in Gaborone and the neighboring villages such as Thamaga, Metsimotlhabe, Mogoditshane, Tlokweng, Gabane, Kumakwane, Oodi and Mochudi responded to a self developed questionnaire. The decision to utilize Gaborone and the neighboring villages for the study was based on its accessibility and close proximity to Gaborone City Centre. 


\section{The Instrument}

A close ended questionnaire was used for data collection. The questionnaire comprised of two sections. Section A of the questionnaire established the biographical information of the respondents and section B attempted to establish the perceptions of the primary school teacher with regards to the Physical Education component of Creative and Performing Arts. The decision to utilize the questionnaire is based on the ability of the tool to capture data from a large number of respondents over a short space of time. The questionnaire was piloted, and tested to acertain its validity and reliability. The Cronbach Alpha was used to test for the reliability of the questionnaire and a score of 0.73 was achieved from the test.

\section{Results}

A total of $19(26.4 \%)$ of the respondents were males while $53(73.6 \%)$ of the respondents were females. This result indicates that there were more females who responded to the study than the males. The ages of the respondents varied, a total of $17(23.6 \%)$ of the respondents were between the ages of $21-30$ years, $30(41.7 \%)$ of the respondents were between the ages of 31 and 40 years, $23(31.9 \%)$ of the respondents were aged between 41 and 50 years and only two (2.8\%) of the respondents were aged between 51 and 60 years. This finding shows that the majority of the respondents were between the ages of 31 and 40 years old.

The following table shows the qualification levels of the respondent teachers.

Table 2. Level of Qualification of Teachers.

\begin{tabular}{|l|l|l|}
\hline Qualification level & Frequency & Percentage (\%) \\
\hline O' levels Certificate & 2 & $2.8 \%$ \\
\hline Primary Teacher's Certificate & 34 & $47.2 \%$ \\
\hline Diploma in Primary Education & 31 & $43.1 \%$ \\
\hline Bachelors of Education in Primary Education & 5 & $6.9 \%$ \\
\hline Total & 72 & $100 \%$ \\
\hline
\end{tabular}

Table 2 above shows the level of qualifications of the respondent teachers. Only two $(2.8 \%)$ of the respondents had acquired the O' Levels Certificate, 34 (42.7\%) of the respondents had Primary Teachers' Certificate, 31 (43.1\%) of the respondent teachers had a Diploma in Primary Education and only 5 (6.9\%) of the respondents had a Bachelors of Education degree in Primary Education. This result indicates that the majority of the respondents had acquired either a Primary Teacher's Certificate or a Diploma in Primary Education. Thus the majority of the respondents were qualified primary school teachers. Morgan and Hansen (2008) have highlighted the importance of adequate qualifications of teachers which enhance their instruction of physical education programs.
In terms of Experience, $19(26.4 \%)$ of the respondents had been teaching in primary schools for between 0 and 5 years, $11(15.3 \%)$ of the respondents had been teaching in primary schools for between 6 and 10 years, $18(25 \%)$ of the respondents had been teaching in primary schools for between 16 and 20 years. A total of $9(12.5 \%)$ of the respondents had been teaching in primary schools for between 21 and 25 years, while only two $(2.8 \%)$ of the respondents had been teaching in primary schools for between 26 and over 30 years. This result shows that teachers with varying degrees of years of experience responded to the study. 
Out of the 72 respondents that participated in the study, $35(48.6 \%)$ of the respondents reported that the knowledge that they had with regards to the Physical Education component of Creative and Performing Arts was adequate to enhance their teaching of the subject. While on the other hand, 37 (51.4\%) of the respondents reported that they did not think that the knowledge that they had with regards to the physical education component of Creative and Performing Arts was adequate to enhance their teaching of the subject. This finding shows that the majority of the respondents did not think that they had adequate knowledge with regards to the physical education component of Creative and Performing Arts. This result is not consistent with the writing of Capel (2005:9) who stated that every teacher needs good knowledge and understanding of the subject content that they are supposed to teach. Furthermore, teacher at the primary schools in Botswana are generalist teachers. Morgan and Hansen (2008) reported that most generalist teachers do not feel confident to teach Physical education and they usually supplement their lack of expertise by involving specialist teachers.

With regards to training, $52(72.2 \%)$ of the respondents reported that they felt that they needed some form of training to enhance their teaching of Creative and Performing Arts to a large extent while 20 (27.8\%) of the respondents reported that they needed some form of training that they needed some form of training to enhance their teaching of creative and Performing Arts to a small or no extend. A total of $22(30.6 \%)$ of the respondents had attended a workshop on Creative and Performing Arts while 50 (69.4\%) of the respondents had never attended a workshop on Creative and Performing Arts. This finding shows that while most teachers reported that they did not have adequate knowledge that would enhance their teaching of the physical education component of creative and performing Arts, not much was done to prepare teachers for this task. Wuest and Bucher (1999) reported that it was necessary for school teacher to be adequately and relevantly trained in order for Physical Education to be beneficial to primary school pupils and to the society at large.
With regards to liking the subject, 50 (69.5\%) of the respondents reported that they did not like Creative and Performing Arts as a subject while 22 (30.5\%) of the respondents reported that they liked Creative and Performing Arts as a subject to a large extent. A total of $53(73.6 \%)$ of the respondents reported that they did not feel that the learners benefitted from Creative and Performing Arts as a subject. This finding shows that the majority of the respondent teacher reported that they did not like Creative and Performing Arts and a majority of the respondents reported that they did not feel that the learners benefitted from Creative and performing Arts. Kim and Taggard (2004) reported that negative perceptions by teachers are a problem for the delivery of quality subjects in the schools.

With regards to teaching the physical education component of Creative and Performing Arts, 52 (72.2\%) of the respondents reported that they enjoyed teaching the physical education component of Creative and Performing Arts while 20 (27.8\%) of the respondents reported that they did not enjoy teaching the physical education component of Creative and Performing Arts. This finding shows that a majority of the respondents reported that they enjoyed teaching the Physical Education component of Creative and Performing Arts. The extent to which teachers like or dislike the subject may have consequences for the subject. In a study conducted by Kim and Taggard (2004) showed that the thoughts and the perceptions teachers have led to teacher arguing for the replacement of physical education with other subjects.

Only $4(5.6 \%)$ of the respondents reported that the equipment needed to teach the physical education component of Creative and Performing Arts was adequate to enhance their instruction. A total of 68 (94.4\%) of the respondents reported that the equipment needed to teach the Physical education component of Creative and Performing Arts was not adequate to enhance their instruction. This result shows that the majority of the respondents reported that the reported that the equipment needed to teach the Physical Education component of Creative and Performing Arts was insufficient to enhance their instruction. Capel (2005) reported that factors such as lack of appropriate facilities and equipment usually make it impossible for pupils to participate fully and efficiently in physical activity during class time. 


\section{Conclusions and Recommendations}

From the findings of the research, the following conclusions can be drawn:

- Lack of knowledge and training with regards to physical education contributes to the teachers' difficulties in teaching the subject.

- The lack of facilities in the schools makes it difficult for the teachers to effectively teach the physical education component of Creative and Performing Arts.

- Most teachers did not enjoy teaching Creative and Performing Arts.

The following recommendations can be drawn following the study:

- Equipment and facilities should be made available to teachers to enhance their teaching of the physical education component of Creative and Performing Arts.

- Short refresher courses should be made for the benefit of teachers so that their knowledge base on the physical education component of Creative and Performing Arts can be improved.

- The physical education component of creative and performing Arts must be taught by specialist teacher as this will ensure that students derive maximum benefit from the subject.

\section{References}

Almond, 1. (1997). Physical Education in Schools. London: Kogan Page Limited.

Behets, D. (2001). Value orientation of Physical education Pre-service and In-service Teachers. Journal of Teaching Physical Education, 20, 144 - 154.

Capel, S. (2005). Learning to Teach Physical Education in the Secondary School $\left(2^{\text {nd }} \mathrm{ed}\right)$. London: Routledge Falmer, Taylor \& Francis Group..Creative and Performing Arts Syllabus (2002). Republic of Botswana. Ministry of Education. Government Printers.

Faulkner, G., \& Reeves, C. (2000). Primary School Student Teacher's Physical self Perceptions and Attitudes towards Teaching Physical Education. Journal of Teaching Physical Education, 19 (3). 311 $-324$.

Gabbard, C., Le Blanc, B., \& Lowy, A. (1994). Physical Education for Children. New Jersey: Prentice Hall.

Guan, J., McBride, R., \& Xiang, P. (2002). Validity and Reliability of Teachers' Attitudes towards Teaching Physical Activity and Fitness Instrument: Chinese Version. Research Quarterly for Exercise and Sport, 73 (1) A $67-68$.

Hopper, B., Grey, J., \& Maude, T. (2000). Teaching Physical Education in the Primary School. London: Routledge Falmer.

Kim, J., \& Taggard, A. (2004). Teachers' Perceptions of the Culture of Physical Education: Investigating the silences of Hana Primary School. www.education. curtin.edu.au/iiier.html. Extracted on $02-11-2005$

Lefrancois, G. R. (2000). Psychology of Teaching (10 ed). New York: Thompson Learning.

Mantanin, M., \& Collier, C. (2003). Longitudinal Analysis of Pre-service Teacher's Beliefs about Teaching Physical Education. Journal of Teaching Physical Education, 19, 206 - 221. 
Mawer, M. (1995). The Effective Teaching of Physical Education. New York: Longman Publishing.

Mokgwathi, M. M. (1999). Sport Pedagogy in Botswana. In Amusa L.O., Toriola A. L. \& Onywadume, I. U. (Eds). Physical education and Sport. In Africa. pp. 121 137. Ibadan. LAP Publications.

Morgan, P., Bourke, S., \& Thompson, K. (2002). The Influence of Personal School Physical Education Experiences on Non-specialist Teacher's Beliefs about Physical Education. Extracted from www.aare.edu. au/02pap/abso2.htm. on $27-10-2005$.

Morgan, P. J., \& Hansen, V. (2008). Physical education in Primary schools : Classroom Teachers perceptions of benefits and outcomes. Health Education Journal, 67 (3), 196 - 208.

Owolabi, E. O. (1997). Physical Education in Botswana Education System. In Owolabi E. O., Kalui, B., Wekesa, M. \& Toriola, A. L. (Eds). Physical Education in Botswana Schools and Colleges. (pp 8 - 12). Gaborone, University of Botswana.

Schempp, P. G. \& Manross, D. (1998). Subject Expertise and Teacher Knowledge. Journal of Teaching Physical Education, 17, 342 - 356 .

Sewane, S., \& Owolabi, E. O. (1996). The Status of Physical education in Botswana Community Schools: A Case of a Primary School. In Owolabi, E. O. \& Adolph J. T. (Eds.) Sport in Botswana: The Way Forward. (pp. 66 - 82). Gaborone, Associated Printers.

Wuest, A. D., \& Bucher, A. C. (1999). Foundations of Physical Education $\left(12^{\text {th }} e d\right)$. New York: Mosby Year Book.

\section{Correspondence:}

Authors:

Lobone L. Kasale; Dr. Martin M. Mokgwathi

Lobone Lloyd Kasale is a lecturer in the

Department of Physical Education,

Health and Recreation at University of Botswana.

Dr. Martin M. Mokgwathi is a Senior lecturer in the Department of Physical Education,

Health and Recreation at University of Botswana.

Institutional affiliation:

Department of Physical Education,

Health and Recreation, University of Botswana,

Gaborone, Botswana.

Postal address:

University of Botswana,

Department of Physical Education,

Health and Recreation, Private Bag 0022,

Gaborone, Botswana.

Telephone number: (0027) 3552064 (work)

(0027) 72775803 (mobile)

Email address: kasalel@mipipi.ub.bw 